\title{
Evaluation of testicular torsion in rats by using the Superb Microvascular Imaging Ultrasound technique comparison with Power Doppler Ultrasound and Color Doppler Ultrasound techniques
}

\author{
Sıçanlarda testis torsiyonu tanısında kullanılan PowerDopplerUltrason ve RenkliDoppler \\ Ultrason tekniğinin Süperb Mikrovasküler Imaging Ultrason tekniği ile karşılaştııılması
}

İncinur Genişol, Ökkaş Aytaç Karkıner, Sinan Genç, Malik Ergin, Soner Duman, Akgün Oral, Münevver Hoşgör

Gönderilme tarihi:01.04.2021

Kabul tarihi:27.05.2021

\begin{abstract}
Aim: Testicular torsion is a surgical emergency. This study aims to evaluate the superiorities of Power Doppler Imaging, Color Doppler Imaging, and Superb Microvascular Imaging to each other in the diagnosis of testicular torsion in rats.

Material and methods: This study included thirty pubertal, 26-30 days old Wistar-Albino male rats weighing 210-262 g. Rats were randomized to 5 groups, including group A-sham, group B-orchiectomy after one hour of torsion, group C-orchiectomy after two hours of torsion, group D-orchiectomy after three hours of torsion, group E-orchiectomy after four hours of torsion. All the rats were followed with Power Doppler Imaging, Color Doppler Imaging, and Superb Microvascular Imaging before torsion, but also group B was done the three ultrasound techniques after torsion's first hour, group $\mathrm{C}$ was done ultrasound after torsion's first and second hours, group $D$ was done ultrasound after the first, second and third hours of torsion, group $E$ was done ultrasound after the first, second, third and fourth hours of torsion. Ultrasound scanning was performed for all rats by the same doctor using a 7-18 MHz linear probe (Aplio 500, Toshiba Medical System Company Tokyo, Japan). The images were assessed with regard to the degree of vascularity and the presence of artifacts. Histologic examination was performed at the designated conclusion of each hour.

Results: Superb Microvascular Imaging had higher staging scores in the torsioned testicles compared to Color Doppler Imaging and Power Doppler Imaging, without a statistical significant difference. After 4-hour ischemia, all three methods gave the same scores. When looking at histopathological staging, a statistical significant difference was found between 1-hour ischemia and 2, 3, and 4-hours ischemia durations. No statistical significant difference was found in histopathological staging performed after 2, 3, and 4-hour ischemia. All three devices were found to be compatible with each other for each hour.

Conclusions: Comparing Superb Microvascular Imaging used to detect testicular torsion, with Power Doppler Imaging and Color Doppler Imaging; all three techniques were found as effective and safe diagnostic methods.
\end{abstract}

Key words: Testicular torsion, superb microvascular imaging, power doppler imaging, color doppler imaging, animal study.

Genisol I, Karkiner OA, Genc S, Ergin M, Duman S, Oral A, Hosgor M. Evaluation of testicular torsion in rats by using the Superb Microvascular Imaging Ultrasound technique comparison with Power Doppler Ultrasound and Color Doppler Ultrasound techniques. Pam Med J 2021;14:854-861.

Öz

Amaç: Testis torsiyonu cerrahi bir acildir. Bu çalışmada sıçanlarda testis torsiyonu tanısında Power Doppler Ultrason, Renkli Doppler Ultrason ve Superb Mikrovasküler Imaging Ultrason tekniklerinin birbirlerine üstünlüklerini değerlendirmeyi amaçlamaktadır.

Gereç ve yöntem: 210-262 gr ağırlığında, 26-30 günlük, 30 pubertal Wistar-Albino erkek sıçanı deneye dahil edildi. Sıçanlar, grup A-sham, bir saatlik torsiyondan sonra grup B-orşiektomi, iki saatlik torsiyondan sonra grup

İncinur Genişol, MD, Pamukkale University Medical School, Pediatric Surgery, Denizli, Turkey, e-mail: incinurgenisol@msn.com (https://orcid. org/0000-0003-3843-5942) (Corresponding Author)

Ökkaş Aytaç Karkıner, MD, Dr. Behçet Uz Children Hospital, Pediatric Surgery, Izmir, Turkey, e-mail: drkarkiner@gmail.com (https://orcid. org/0000-0003-1504-2628)

Sinan Genç, MD, Dr. Behçet Uz Children Hospital, Radiology, Izmir, Turkey, e-mail: sinan_genc@yahoo.com (https://orcid.org/0000-0002-05161028)

Malik Ergin, MD, Dr. Behçet Uz Children Hospital, Pathology, Izmir, Turkey, e-mail: mergin1969@yahoo.com (https://orcid.org/0000-0002-19279609)

Soner Duman, Prof. Ege University Medical School, Internal Medicine, Izmir, Turkey, e-mail: sonerduman@hotmail.com (https://orcid.org/00000002-7232-9660)

Akgün Oral, Prof. Dr. Behçet Uz Children Hospital, Pediatric Surgery, Izmir, Turkey, e-mail: ak_oral@hotmail.com (https://orcid.org/0000-00025250-7335)

Münevver Hoşgör, Prof, Dr. Behçet Uz Children Hospital, Pediatric Surgery, İzmir, Turkey, e-mail: münevver.hosgor@gmail.com (https://orcid. org/0000-0002-9078-187X) 
D-orşiektomi, üç saatlik torsiyondan sonra grup C-orşiektomi, dört saat sonra grup C-orşiektomi grubu olmak üzere 5 gruba randomize olarak ayrıldı. Tüm sıçanlar torsiyondan önce Power Doppler Görüntüleme, Renkli Doppler Görüntüleme ve Süper Mikrovasküler Görüntüleme ile takip edildi, ancak torsiyonun birinci saatinden sonra B grubuna üç ultrason tekniği, torsiyonun birinci ve ikinci saatlerinden sonra grup C'ye üç ultrason tekniği ile, grup D torsiyonun birinci, ikinci ve üçüncü saatlerinden sonra her üç ultrason tekniği ile, grup E'ye ise torsiyonun birinci, ikinci, üçüncü ve dördüncü saatlerinden sonra her üç ultrason tekniği ile ultrason yapıldı. Tüm sıçanlara aynı doktor tarafından 7-18 MHz lineer prob kullanılarak ultrason taraması yapıldı. Görüntüler, damarlanma derecesi ve artefaktların varlığı açısından değerlendirildi. Her grubun torsiyon süresi sonunda orşiektomi yapılması ile histopatolojik değerlendirme yapıldı.

Bulgular: Superb Mikrovasküler Imaging Ultrason, torsiyonlu testislerde Renkli Doppler Ultrason ve Power Doppler Ultrasona göre kıyasla istatistiksel olarak anlamlı bir fark olmaksızın daha yüksek evreleme puanlarına sahipti. 4 saatlik iskemiden sonra, her üç yönteme de aynı puanları verdi. Histopatolojik evrelemeye bakıldığında 1 saatlik iskemi ile 2, 3 ve 4 saatlik iskemi süreleri arasında anlamlı fark bulundu. 2, 3 ve 4 saatlik iskemiden sonra yapılan histopatolojik evrelemede anlamlı bir fark bulunmadı. Her üç cihazın da her saat için birbiriyle uyumlu olduğu görüldü.

Sonuç: Testis torsiyonunu saptamak için kullanılan Superb Mikrovasküler Imaging Ultrason, Power Doppler Ultrason ve Renkli Doppler Ultrason ile karşılaştırılmasında her üç teknik de etkili ve güvenli tanı yöntemleri olarak bulundu.

Anahtar kelimeler: Testis torsiyonu, süperb mikrovasküler imaging ultrason, power doppler ultrason, renkli doppler ultrason, sıçan deneyi.

Genişol I, Karkıner ÖA, Genç S, Ergin M, Duman S, Oral A, Hoşgör M. Sıçanlarda testis torsiyonu tanısında kullanılan Power Doppler Ultrason ve Renkli Doppler Ultrason tekniğinin Süperb Mikrovasküler Imaging Ultrason tekniği ile karşılaştırılması. Pam Tıp Derg 2021;14:854-861.

\section{Introduction}

Testicular torsion is a surgical emergency that requires rapid diagnosis and treatment, leading to the acute scrotum in childhood and causes permanent ischemic damage to the testicle [1]. This condition is caused by the blocked blood flow of the testicles and its appendages due to the rotation of the spermatic cord around its axis [2]. The cause is testicular torsion in $15 \%$ of patients who apply with acute scrotum $[3,4]$. It peaks in two age groups, generally in the neonatal period and $12-18$ years [5]. If correct diagnosis and proper treatment cannot be achieved within the first 6 hours, irreversible ischemic damage causes the testicle on that side to be lost $[6,7]$. Therefore, a rapid diagnosis should be made, and manual detorsion and/or surgical exploration should be performed for treatment [6, 8]. Although imaging techniques used in the diagnosis of diseases that cause acute scrotum development, it is not always easy to make a definite diagnosis. Power Doppler Imaging (PDI) is the most frequently used, rapidly responsive, non-invasive, gold standard method for the imaging of torsioned testicles [9-11]. However, the rate of misdiagnosis was found to be $7-10 \%$ by pediatric urologists and $45 \%$ by family physicians.

The absence of blood flow in PDI is in favor of testicular torsion. There are new publications reporting that Superb Microvascular Imaging (SMI), which has been used in recent years, gives more information about parenchymal perfusion [8, 12]. The reason for preferring SMI is because it shows the tissue perfusion better, responds in a shorter time, is non-invasive, and does not emit radiation, and it is used to detect small vessels and low-velocity blood flow $[8,13]$. This study aims to compare the superiorities of PDI, Color Doppler Imaging (CDI), and SMI to each other in the diagnosis of testicular torsion. The study was carried out in the form of animal experiments since the comparison of all three techniques will increase the response time and damage in the tissue in patients with testicular torsion. Rats were preferred as experimental animals since the size of the rat testicle is appropriate, easy surgical intervention can be performed, and imaging can be easily performed with the ultrasound probe.

\section{Materials and methods}

\section{Study Groups, anesthesia and surgical intervention}

Ethical approval was obtained in line with the decision taken in the session dated 23 August 2016, and decision number is 01/16/2016 of Dokuz Eylül University Multidisciplinary Laboratory Animal Experiments Local Ethics Committee. 
Pubertal, 26-30 days old Wistar-Albino male rats weighing 210-262 g, produced by Dokuz Eylül University Multidisciplinary Laboratory, were used. Subjects were kept at $22 \pm 1^{\circ} \mathrm{C}$ at Dokuz Eylül University Multidisciplinary Laboratory, in an environment that was darkened for 12 hours, lightened for 12 hours, and humidified at a ratio of $50-60 \%$. Standard pellet feed and city potable water were used to feed the rats until the day of the experiment. No support was received for expenses. The histopathology of the tissues excised at the end of the experiment was studied by Dr. Behcet Uz Children's Hospital Pathology Laboratory.

General anesthesia was applied to the subjects by administering $5-10 \mathrm{mg} / \mathrm{kg}$ dose of xylazine (Rompun, Bayer-ìstanbul) and 50-70 $\mathrm{mg} / \mathrm{kg}$ dose of ketamine hydrochloride (Ketalar, Pfizer-İstanbul) intramuscularly. Scrotum skin was cleaned with a $10 \%$ povidone-iodine solution. Ultrasound was performed on all scrotums in the supine position by the same pediatric radiologist with a $7-18 \mathrm{MHz}$ linear probe. The blood flow was staged by PDI, CDI, and SMI as follows: Stage 0, no blood flow; stage 1, blood flow in one or two focal areas; stage 2, blood flow in one linear or more focal areas; stage 3, multiple linear blood flow [12] (Table 1).

After imaging procedures, two $\mathrm{cm}$ long vertical skin and subcutaneous incisions were applied to the subjects on the midline of the scrotum. After the first ultrasonographic imaging of the testes of the rats in all groups, orchiectomy was applied to the testicles of the rats in the Group A-sham group. The experimental extravaginal testicular torsion model was created by rotating the left testicles of the other subjects 720 degrees clockwise with the cord elements (Figure 1). The torsioned testicle was fixed in the inner scrotum surface from two locations with $6 / 0$ polydioxanone (PDS) sutures. The testicle was placed back into the scrotum. At the end of one-hour torsion, re-imaging was obtained from the remaining 24 subjects, the incision was opened, and bilateral orchiectomy was applied to 6 of the subjects (Group B) (Figure 2). During the next two hours of torsion, second-hour images were taken from 18 subjects, and bilateral orchiectomy was

Table 1. Ultrasonography grading

\begin{tabular}{ll}
\hline & Testicular Vascularity Grading \\
\hline Stage 0 & No blood flow \\
Stage 1 & Blood flow in one or two focal areas \\
Stage 2 & Blood flow in one linear or more focal area \\
Stage 3 & Multiple linear blood flow \\
\hline
\end{tabular}

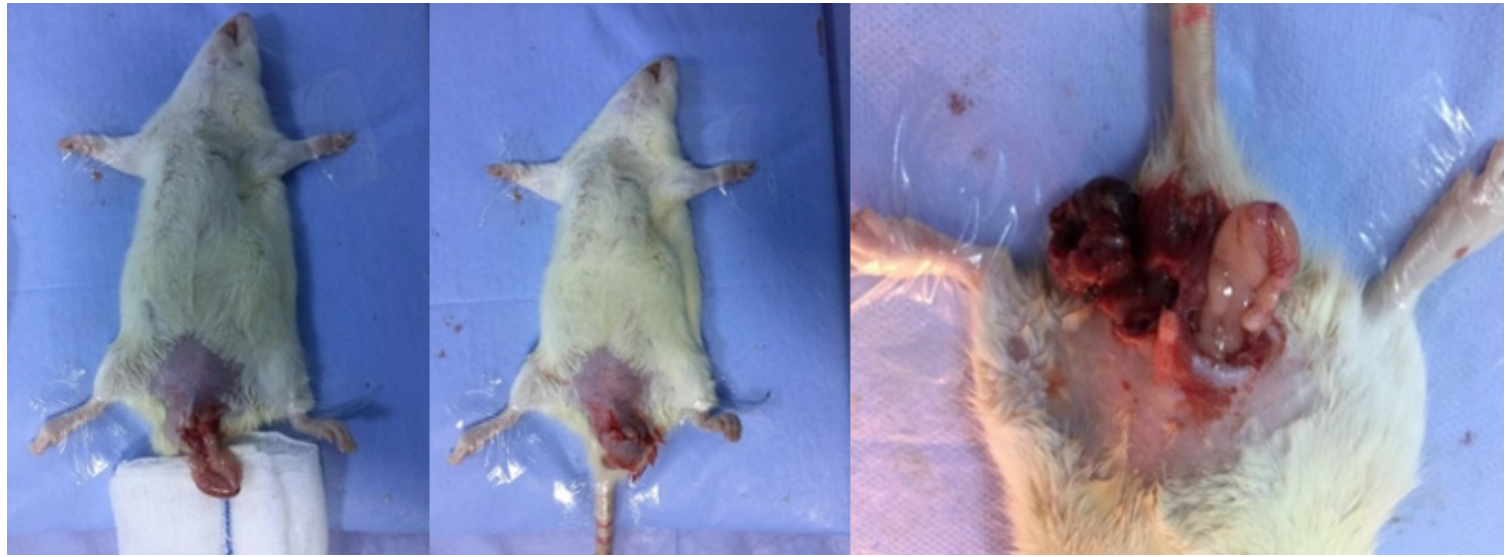

Figure 1. Extravaginal testicular torsion in the rat testis 
performed on six subjects (Group C) at the end of the second hour. During the three-hour torsion, third-hour images were taken from 12 subjects, and bilateral orchiectomy was performed on six subjects (Group D) at the end of the third hour. The last six subjects (Group E) within four-hour torsion; bilateral orchiectomy was applied to all of them at the end of the fourth hour. At the end of the surgical procedures, cervical dislocation was performed on all subjects.

\section{Histopathological examination}

Testicular tissues were fixated in $10 \%$ formaldehyde solution after orchiectomy for histopathological examination and sent to Dr. Behçet Uz Children's Hospital Pathology Laboratory. Samples that were followed-up after fixation were blocked with paraffin. Standard sections with a thickness of four microns were prepared for microscopic examination

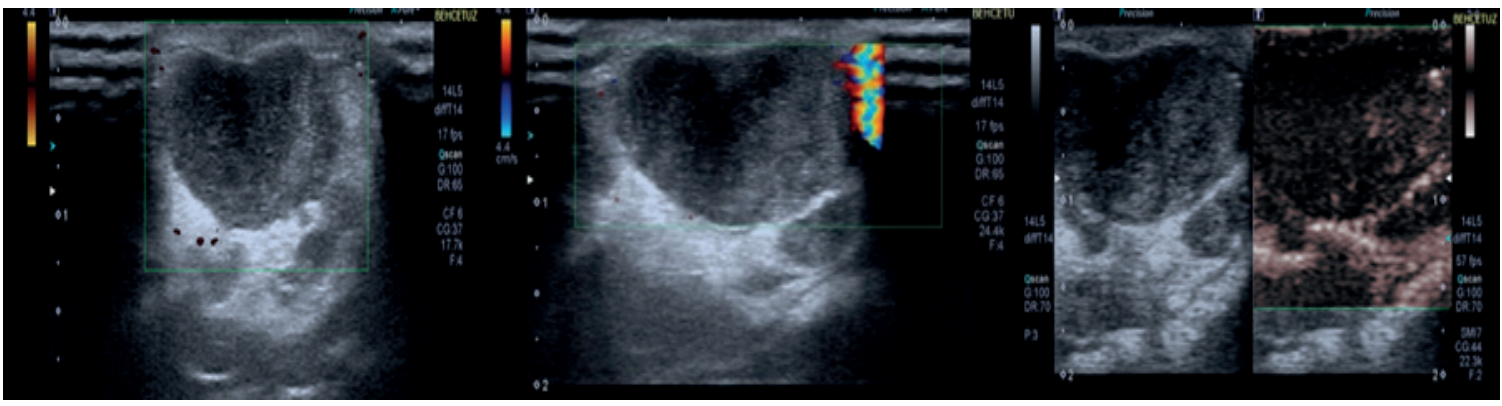

Figure 2. PDI, CDI and SMI images in the same testis at one clock after torsion

by staining with Hematoxylin-Eosin (H\&E). All preparations were examined and staged by the same pathology specialist under the light microscope (NikonEclipse E400, Tokyo, Japan) with $\times 100$ and $\times 200$ magnifications as follows: Stage 1; normal testicular tissue with regular sequenced germ cells. Stage 2; less regular germ cells and irregularly narrowed seminiferous tubules. Stage 3; shrunken pyknotic nucleus and seminiferous tubules with distorted borders. Stage 4; seminiferous tubules filled with irregular germ cells with coagulated necrosis [14] (Table 2).

\section{Statistical analysis}

SPSS Windows v.21.0 was used for the analysis. Data were given as mean \pm standard deviation (SD). Histopathological data were evaluated by Kruskal-Wallis variance analysis. Mann-Whitney $U$ test was used for inter-group comparisons. Bonferroni correction was made. Flow staging scores between three USG devices were compared by using the Friedman test. Wilcoxon test was used in paired comparisons.
Compatibility analysis of the three devices was performed with weighted kappa. $P<0.05$ was considered statistically significant.

\section{Results}

The subjects were divided into 5 groups and there was no loss of rats from any group. Before the torsion, the echogenicity of the testes of all rats was homogeneous. Average testicular volumes were found to be $1756 \pm 423 \mathrm{~mm}^{3}$. The blood supply of all testicles in PDI was evaluated as Stage 3. In CDI, the left testicle of two of the rats was evaluated as Stage 2(one of Group D and the other one is Group E), and the blood supply of the remaining testicles was evaluated as Stage 3. In SMI, blood supply of all testicles was evaluated as Stage 3.

At the 1st hour of the torsion, the blood supply of the testicle of 1 rat in Group C in PDI is Stage 1, the blood supply of the torsion testicle of a rat in Group B is Stage 2, and the blood supply of the 22 testicles is Stage 0 . In CDI, the blood supply of the same testicle, which was in

Table 2. Histopathological grading

\begin{tabular}{ll}
\hline Stage 1 & Normal testicular tissue with regular sequenced germ cells \\
\hline Stage 2 & Less regular germ cells and irregularly narrowed seminiferous tubules \\
Stage 3 & Shrunken pyknotic nucleus and seminiferous tubules with distorted borders \\
Stage 4 & Seminiferous tubules filled with irregular germ cells with coagulated necrosis \\
\hline
\end{tabular}


Group B and had testicular blood in Stage 2 in PDI, came as Stage 2, in PDI, the blood supply of the same testicle with testicular blood in Stage 0 came in Stage 2, and the blood supply of the remaining 20 testicles came as Stage 0 . Testicular blood in PDI and CDI blood in the same testicle in Group B with Stage 2 SMI in Stage 3. Stage 2 in CDI blood in the testicle in Group C, SMI in Stage 3. PDI in Stage 1, the blood in the testicle in Group D came as Stage 2. In PDI and CDI, 1 testicle in Group B came as Stage 0, 3 testicles were Stage 1, and 1 testicle was Stage 2. In PDI and CDI, the blood supply of 1 testicle in SMI from the testicles in Group C, which is at Stage 0 , Stage 0 , the blood supply of 3 testicles Stage 1, the blood supply of 1 testicle Stage 2 came. PDI and CDI were evaluated as Stage 0 in Group D, 2 testes in SMI were Stage 0,2 testicles were Stage 1 and 1 testicle was Stage 2. 4 testes of the testicles evaluated as Stage 0 in PDI and CDI came as Stage 0 in SMI, and 2 testes as Stage 1.

At the second hour of the torsion, the blood supply of all testicles $(n=18)$ in PDI and CDI came as Stage 0. However, in SMI in Group C, 1 testicle was Stage 3, 2 testicles in Group D was Stage 1, 2 testes in Group E were Stage 1, and the blood supply of 13 testicles was Stage 0 .

At the third hour of the torsion, the blood supply of all testicles $(n=12)$ in PDI and CDI came as Stage 0. However, in SMI in Group D, the blood supply of 2 testicles was Stage 1 , and the blood supply of 10 testicles was Stage 0 .
At the 4th hour of the torsion, the blood supply of all testicles in PDI, CDI and SMI was Stage 0.

A total of 30 testes in Group A, B, C, D, E were staged histopathologically. All testicles in Group A were pathologically Stage 1.2 testicles in Group B were Stage 2, and 4 testicles were Stage 3. All testicles in Group C and D were Stage 3. 4 testicles in the group were Stage 3, and 2 testes were Stage 4 .

When staging of three devices was compared, it was observed that the evaluations made with SMI had higher scores in the torsioned testicles compared to CDI and PDI, except for 4-hour ischemia. However, this difference was not considered to be statistically significant. When the staging scores after 4- hour ischemia were compared, all three methods yielded the same scores. Staging scores made with CDI and PDI devices were always found similar.

When looking at histopathological staging, a statistical significant difference was found between 1-hour ischemia and 2, 3, and 4-hours ischemia durations $(p=0.02)$. No statistical significant difference was found in histopathological staging performed after 2, 3, and 4-hour ischemia. When the compatibility analysis of the three devices was evaluated, all three devices were found to be compatible with each other for each hour (Table 3, 4).

\section{Discussion}

Testicular torsion is a surgical emergency,

Table 3. Comparison of grading scores among PDI, CDI and SMI

\begin{tabular}{|c|c|c|c|c|}
\hline & PDI Mean \pm SD & CDI Mean $\pm S D$ & SMI Mean $\pm S D$ & $p^{*}$ value \\
\hline Baseline all testes $(n=60)$ & $3.0 \pm 0.0$ & $2.9 \pm 0.1$ & $3.0 \pm 0.0$ & 0.135 \\
\hline 1 hour ischemia torsioned testis $(n=24)$ & $0.1 \pm 0.4$ & $0.2 \pm 0.6$ & $0.3 \pm 0.6$ & 0.368 \\
\hline 2 hours ischemia torsioned testis $(n=18)$ & $0.0 \pm 0.0$ & $0.0 \pm 0.0$ & $0.1 \pm 0.3$ & 0.146 \\
\hline 3 hours ischemia torsioned testis $(n=12)$ & $0.0 \pm 0.0$ & $0.0 \pm 0.0$ & $0.1 \pm 0.3$ & 0.135 \\
\hline 4 hours ischemia torsioned testis $(n=6)$ & $0.0 \pm 0.0$ & $0.0 \pm 0.0$ & $0.0 \pm 0.0$ & 0.986 \\
\hline
\end{tabular}

${ }^{*}$ Friedman test

PDI: Power Doppler Imaging, CDI: Color Doppler Imaging, SMI: Superb Microvascular Imaging, SD: Standard Deviation 
Table 4. Agreement of three devices

\begin{tabular}{lllllll}
\hline & \multicolumn{2}{c}{ PDI vs CDI } & \multicolumn{2}{c}{ PDI vs SMI } & \multicolumn{2}{c}{ CDI vs SMI } \\
\hline & Kappa value & $\boldsymbol{p}$-value & Kappa value & $\boldsymbol{p}$-value & Kappa value & $\boldsymbol{p}$-value \\
1 hour ischemia & 0.916 & $<0.01$ & 0.702 & $<0.01$ & 0.673 & $<0.01$ \\
2 hours ischemia & 0.944 & $<0.01$ & 0.87 & $<0.01$ & 0.815 & $<0.01$ \\
3 hours ischemia & 0.944 & $<0.01$ & 0.889 & $<0.01$ & 0.944 & $<0.01$ \\
4 hours ischemia & 0.944 & $<0.01$ & 0.944 & $<0.01$ & 1 & $<0.01$ \\
\hline
\end{tabular}

Correlation strengths interpreted as: $<0$ less than chance agreement,

0.01-0.20 slight agreement 0.21-0.40 fair agreement,

$0.41-0.60$ moderate agreement, $0.61-0.80$ substantial agreement,

$0.81-0.99$ almost perfect agreement

PDI: Power Doppler Imaging, CDI: Color Doppler Imaging, SMI: Superb Microvascular Imaging

and treatment delay often results in the loss of a testicle. In this study, the superiority of PDI, $\mathrm{CDI}$, and SMI techniques was compared in the experimental unilateral testicular torsion model. This study is the first randomized and controlled study to evaluate the use and effectiveness of $\mathrm{SMI}$ in the diagnosis of testicular torsion.

While establishing our experimental model, we used 26-30 day old rats that match the testicular torsion age group with no sexual reproduction capacity, since testicular torsion is common before puberty. In our study, it was observed that there was an infarct in the testicles at the first hour of the torsion, there was no increase in congestion at the second hour, but disorganization started in the seminiferous tubules. The venous congestion increased, and the infarct in the testicle became evident. No change was found in volume at the third hour of the torsion due to the arterial blockage along with venous congestion. Infarction occurred in the entire testicle in 4 hours of torsion, and seminiferous tubules and basal membrane integrity were impaired. The testicle was heterogeneous due to the extensive infarct that occurred at the fourth hour of the torsion. However, due to venous congestion and arterial blockage, no blood flow was detected after the second hour. Cosentino et al. [15] found that the most severe changes occurred after three hours and later when they examined the testicles after torsion for different periods. In our study, we found that histopathologically findings are worsened after the second hour of testicular torsion in rats.

The SMI USG device used in this study is a non-invasive technique showing tissue blood flow [16]. It has been used as a vascular imaging technique for breast, thyroid, brain masses, and undescended testicle in various publications [12, 16-19]. The SMI technique is used by loading a different program in the same ultrasonography device. Unlike Doppler ultrasonography, it has been reported in publications that it prevents movement-related artifacts and shows blood supply better [12]. Since we know that ultrasonography is difficult to do because children are very mobile, we aimed to get more accurate results with this technique.

Although SMI USG is a USG technique is capable of showing even micro blood flows, there is not enough data on the effectiveness of this technology in determining the blood flow of the testicle [17]. Therefore, we aimed to show even minimal blood flow in torsioned testicle tissue. In the USG evaluation, SMI and PDI and CDI were compared, and stage 1-2-3 blood flow from SMI USG was considered significant for the testicle, which was accepted as Stage 0 (no blood build-up) in Doppler examinations, and histopathological evaluation after orchiectomy was performed according to the classification described by Cosentino et al. [15]. When looking at the results of our study, no statistical significant difference was found between SMI and PDI and CDI in torsioned testicles in the four experimental groups. However, in testicles with extensive infarction and coagulation necrosis in histopathological evaluation, it was thought that tissue blood flow could be misinterpreted as normal due to the minimal blood flow imaging with SMI. Therefore, with SMI, which can be used in the diagnosis of testicular torsion, we think that it should not be perceived that the testicle that has gone into necrosis can be left in its place during the surgical procedure. At the end of the experiment, color changes due to hemorrhage secondary to trauma during orchiectomy were observed in macroscopy of all of the torsioned 
testicles. Because of the sudden changes in circulation, edema and vascular congestion were also observed in the early period and even in the non-torsioned testicle. The reason for this may be that when the testicular torsion occludes the veins, the arteries do not accompany, and finally, edema that occurs, widespread ischemia, or hemorrhagic infarction in the testicle can be seen [20]. Degenerate seminiferous tubules and germ cells with pyknotic nucleus were noteworthy in a few of the torsioned testicles. The clinical study by Puri et al. [21] in which prepubertal patients were subjected; examined the testicles after puberty, in which severe necrosis was detected but left in the scrotum with the hope of showing a little testicular function, they observed severe atrophy in the detorsioned testicles, sperm examinations of these testicles were found to be normal, and all married people had children. In our study, since orchiectomy was performed at the early histopathological stage, it does not give an idea about the future damage and autoimmune damage to the contralateral testicle. However, due to hypoxia and ischemia, germ cell and Leydig cell loss are observed, even in the early period, and this situation gets worse within hours. Therefore, it is very important to make an accurate diagnosis in the early period.

Comparing SMI used to detect testicular torsion, which is a surgical emergency requiring rapid evaluation and intervention with $\mathrm{PDI}$ and CDI, all three techniques were found as effective and safe diagnostic methods. As testicular torsion in rats results in necrosis after 2nd hour for 720 degrees, there is no need to continue the experiment for 3th and 4th hours for this study.

This study has several limitations. Firstly, since our study was conducted under anesthesia, there was no need for screening in PDI to prevent artifacts caused by movement, and even low currents could be displayed. Therefore, we recommend the study to be used in active boys and re-evaluate the results. The second limitation is the histologic assessment of the torsed testicle was based on the pathologist's reading, not on an objective evaluation using a grading system. The third one is that we used $7-18 \mathrm{MHz}$ linear probe for ultrasonography, but the rat testicle is smaller than newborn child testicle. At the same time other differential diagnoses that caused acute scrotum were not included in the study. The last limitation we found in this article is to use the SMI technique in other organs and to determine which tissue shows better blood supply.

Conflict of interest: No conflict of interest was declared by the authors.

\section{References}

1. Knight PJ, Vassy LE. The diagnosis and treatment of the acute scrotum in children and adolescents. 1984;200:664-673. https://doi.org/10.1097/00000658198411000-00019

2. Başaklar ACJB. Palme Yayıncılık, Ankara, Bebek ve çocukların cerrahi ve ürolojik hastalıkları. 2006:965968.

3. Liang T, Metcalfe P, Sevcik W, Noga M. Retrospective review of diagnosis and treatment in children presenting to the pediatric department with acute scrotum. AJR Am J Roentgenol 2013;200:444-449. https://doi. org/10.2214/AJR.12.10036

4. Atallah MW, Mazzarino AF, Horton BF. Testicular scan, diagnosis and followup for torsion of testis. J Urol 1977;118:120-121. https://doi.org/10.1016/s00225347(17)57916-1

5. Jefferson RH, Perez LM, Joseph DB. Critical analysis of the clinical presentation of acute scrotum: a 9-year experience at a single institution. J Urol 1997;158:1198200. https://doi.org/10.1097/00005392-19970900000134

6. Kapoor S. Testicular torsion: a race against time. Int J Clin Pract 2008;62:821-827. https://doi.org/10.1111/ j.1742-1241.2008.01727.x

7. Hayn MH, Herz DB, Bellinger MF, Schneck FX. Intermittent torsion of the spermatic cord portends an increased risk of acute testicular infarction. J Urol 2008;180:1729-1732. https://doi.org/10.1016/j. juro.2008.03.101

8. Vasdev N, Chadwick D, Thomas D. The acute pediatric scrotum: presentation, differential diagnosis and management. Curr Urol 2012;6:57-61. https://doi. org/10.1159/000343509

9. Burks DD, Markey BJ, Burkhard TK, Balsara ZN, Haluszka MM, Canning DA. Suspected testicular torsion and ischemia: evaluation with color Doppler sonography. Radiology 1990;175:815-821. https://doi. org/10.1148/radiology.175.3.2188301

10. Atkinson GO, Patrick LE, JrBall TI, Stephenson $\mathrm{CA}$, Broecker BH, Woodard JR. The normal and abnormal scrotum in children: evaluation with color Doppler sonography. AJR Am J Roentgenol 1992;158:613-617. https://doi.org/10.2214/ ajr.158.3.1739005

11. Liu CC, Huang SP, Chou YH, et al. Clinical presentation of acute scrotum in young males. Kaohsiung $\mathrm{J}$ Med Sci 2007;23:281-286. https://doi.org/10.1016/S1607- 
$551 \times(09) 70410-3$

12. Lee YS, Kim MJ, Han SW, et al. Superb microvascular imaging for the detection of parenchymal perfusion in normal and undescended testes in young children. Eur J Radiol 201;85:649-656. https://doi.org/10.1016/j. ejrad.2015.12.023

13. Zhan J, Diao XH, Jin JM, Chen L, Chen Y. Superb microvascular imaging-a new vascular detecting ultrasonographic technique for avascular breast masses: a preliminary study. Eur J Radiol 2016;85:915921. https://doi.org/10.1016/j.ejrad.2015.12.011

14. Geiger J, Epelman M, Darge K. The fountain sign: a novel color Doppler sonographic finding for the diagnosis of acute idiopathic scrotal edema. J Ultrasound Med 2010;29:1233-1237. https://doi. org/10.7863/jum.2010.29.8.1233

15. Cosentino MJ, M Nishida M, Rabinowitz R, Cockett AT. Histological changes occurring in the contralateral testes of prepubertal rats subjected to various durations of unilateral spermatic cord torsion. J Urol 1985;133:906-911. https://doi.org/10.1016/s00225347(17)49278-0

16. Bonacchi G, Becciolini M, Seghieri M. Superb microvascular imaging: a potential tool in the detection of FNH. J Ultrasound 2017;20:179-180. https://doi. org/10.1007/s40477-017-0240-y

17. Karaca L, Oral A, Kantarci M, et al. Comparison of the superb microvascular imaging technique and the color Doppler techniques for evaluating children's testicular blood flow. Eur Rev Med Pharmacol Sci 2016;20:19471953.

18. Ohno Y, Fujimoto T, Shibata Y. A new era in diagnostic ultrasound, superb microvascular imaging: preliminary results in pediatric hepato-gastrointestinal disorders. Eur J Pediatr Surg 2017;27:20-25. https://doi. org/10.1055/s-0036-1593381

19. Boettcher M, Krebs T, Bergholz R, Wenke K, Aronson $D$, Reinshagen AK. Clinical and sonographic features predict testicular torsion in children: a prospective study. BJU Int 2013;112:1201-1206. https://doi. org/10.1111/bju.12229

20. Heindel RM, Pakyz RE, Reinking LN, Cosentino MJ. The effect of various degrees of unilateral spermatic cord torsion on fertility in the rat. J Urol 1990;144:366369. https://doi.org/10.1016/s0022-5347(17)39462-4

21. Puri, P, Barton D, O'Donnell B. Prepubertal testicular torsion: subsequent fertility. J Pediatr Surg 1985;20:598601. https://doi.org/10.1016/s0022-3468(85)80006-3

Ethics committee approval: Ethical approval was obtained in line with the decision taken in the session dated 23 August 2016, and decision number is 01/16/2016 of Dokuz Eylül University Multidisciplinary Laboratory Animal Experiments Local Ethics Committee.

\section{Contribution of the authors}

Study conception and design: A.K., I.G., A.O. Acquisition of data: I.G., S.G., M.E., S.D. Analysis and interpretation of data: I.G., S.D. Drafting of manuscript: I.G., A.O., M.H. Critical revision: I.G. All the authors approved the final version to be published; all authors agreed to all aspects of the work. 